\title{
The relationship between loss, macroeconomic condition and conservatism
}

\author{
Asna Abdullah Atqa ${ }^{a^{*}}$, Norman Mohd Saleh ${ }^{b}$, Azlina Ahmad $^{\mathrm{b}}$ and Radziah Abdul Latiff $^{\mathrm{b}}$
}

${ }^{a}$ Faculty of Economics \& Management, University Putra Malaysia, Malaysia

${ }^{b}$ Faculty of Economics \& Management, University Kebangsaan Malaysia

\begin{tabular}{l}
\hline C H R O N I C L E \\
\hline Article history: \\
Received: April 6, 2019 \\
Received in revised format: April \\
202019 \\
Accepted: May 6, 2019 \\
Available online: \\
May 6, 2019 \\
\hline Keywords: \\
Loss \\
Conservatism \\
Macroeconomic condition \\
Life-cycle hypothesis
\end{tabular}

\section{A B S T R A C T}

\begin{abstract}
This study is motivated by the high frequency of loss occurrence since late 1990s among Malaysian public listed firms, and the conflicting findings of the impact of the macroeconomic conditions and firm-specific attributes on different measures of earnings quality. In addition, this study examines the impact of firms' specific attributes on earnings quality using a better established theory, known as the life-cycle hypothesis. The objectives of this study are; (1) to examine the relationship between firms' loss condition on conservatism as an earnings quality measure as well as the moderation of macroeconomic condition on the relationship and (2) to examine the relationship between life-cycle stages and conditional conservatism. Samples for the study are companies listed on Bursa Malaysia from 1995 to 2010. Using the C_Score measure of conservatism as the dependent variable, firms with loss condition, have been found to be significantly more conservative than profit firms. In addition, macroeconomic condition, strengthen the relationship between loss and conservatism when the results indicate that loss firms undergoing economic crisis are significantly more conservative than loss firms under normal economic condition. Incorporating the firms' life-cycle stages, the study found that growth firms signal fewer losses than mature firms, thus accepting the set hypothesis. Implication of this study is that ignorance of these issues could lead to significantly misleading interpretation of earnings quality.
\end{abstract}

\section{Introduction}

The focus and main contribution of this study are to examine the relationship of the three variables of interests against conservatism as an earnings quality measure and identify the existence of biasness, if any, within the analysis of the three variables. It should be noted that the recorded inconsistencies in earnings quality research, specifically conservatism, might have come as a result of the inadequacy in examination of firms' economic attributes as well as the underlying measurement of financial performance. Dechow et al. (2010) in their review of earnings quality measures defined earnings quality as jointly determined by the relevance of underlying financial performance to any kind of decisions and by the ability of the accounting system to measure performance. The kinds of decisions undertaken by firms do not confine to equity valuation decisions only, but include other aspects such as stewardship and

\footnotetext{
* Corresponding author.

E-mail address: metegirgen@zohomail.eu (M. Girgen) 
monitoring decisions. Studies found that not all firms reporting the same operating results and/or financial conditions have the same or similar market values (Park \& Chen, 2006) and earnings quality (Chen, Yang \& Huang, 2010b).

Earnings quality is driven by accounting measurement rules and economic attributes and these would result in different valuations and quality although they have similar financial and operating conditions (Anthony \& Ramesh, 1992; Black, 1998; Charitou et al., 2011). Despite the importance of loss condition, macroeconomic condition and life-cycle stages in their own fields and the established theoretical impacts of these factors on earnings quality (especially the value relevance construct) (Burgstahler, Jiambalvo \& Noreen, 1989; Charitou et al., 2011; Francis et al., 2008b; Klein \& Marquardt, 2006; Meek \& Meek, 2009 (on negative earnings and losses); Balakrishnan, 2010; Bertomeu \& Magee, 2011; Chen et al., 1986; Sutthachai \& Cooke, 2009 (on business cycles and economic crises); Anthony \& Ramesh, 1992; Park \& Chen, 2006 (on firms' life-cycle theory)), very few studies have examined them in the context of conservatism.

The rise of loss incidence and the series of economic crisis including the sequence of business cycles (recurrence of expansions and contractions phase one after another) throughout the world in the last few decades pose questions on the impact that these factors have on earnings quality. Question like to what extent quality of reports of loss firms differ from profitable firms given the differential incentives caused by different characteristics and life-cycle stages come into the picture. It is also a concern whether firms' financial statements produced in different macroeconomic conditions differ in quality and affect the economic decisions and performance of firms. The acknowledgement that performance and growth of firms play significant roles in models of earnings quality attributes heightened the importance of this research through the use of a more thorough concept of life-cycle hypothesis. It is hoped that the emergence of life-cycle hypothesis and the tightened findings on earnings quality of loss firms as well as firms undergoing different macroeconomic conditions would assist researchers in finding more concrete conclusions about firms' behaviour (including their reporting quality) which in turn becomes input for firms' financial and economic decision-makings.

The signalling of information quality using measures such as conservatism provides indicators about the underlying financial performance of firms and the ability of accounting system to measure the performance and to produce such desired earnings that are considered unbiased and neutral (Dechow et al., 2010; Lo, 2008). This study chooses signalling theory as an overarching theory linking each of the examined variables. The signalling theory is concerned with reducing information asymmetries between two parties through deliberate communications of positive information by signallers to convey positive attributes about individual, products or organisations such as firms to the receivers (Connelly, Certo, Ireland \& Reutzel, 2011). There are, however, occasions where signals (including negative signals) are perceived differently by receivers which deviate from the intention of signallers, either positively or negatively. A point to note is that signallers would not signal negative signal with the intention to reduce information asymmetry. In this case, the intentions of signallers would be explained by other supporting theories established in the extant literature. However, as Connelly et al. (2011) pointed out, false signalling for whatever reasons would be finally exposed and not dealt with due to the existence of market mechanism where receivers would ignore false information in the long-run. Conservatism principle, in essence, would evaluate the quality of information signalled, through the measure of timely loss recognition. Although it cannot measure precisely and accurately the quality of firms at large, whether they are high quality or low quality signallers, conservatism measure of earnings quality has its own standing as it is calculated over a considerably long period of time to allow correction by the market. In relation to loss condition, firms which signal loss information may be perceived to show positive signals due to higher information disclosure by loss firms such as investments and R\&D expenditure, and innovation activities (Ahmed \& Jinan, 2011; Darrough \& Ye, 2007; Gu \& Li, 2003). They also may be perceived to show negative signals from transitory and recurring losses due to real reduction in economic performance (Hayn, 1995). Loss firms are expected to signal information differently from profit firms due to the nature 
of losses and the signalling process itself. With regard to macroeconomic conditions, similar notion applies where firms undergoing economic crisis, would signal information differently from firms not undergoing crisis period. The macroeconomic condition plays a role in influencing the level of firms' signalling, especially in terms of information conservatism level. In relation to life-cycle stages, firms in different stages would also signal information differently from each other. The signalled information may be similar across firms but the different conditions and firms' characteristics facing each firm would compel them to signal the information differently in terms of earnings quality, particularly the conservatism level. From here, the issue of biasness of conservatism may prop up directly or indirectly when the objectives of the study are fulfilled.

In this study, the conservatism definition takes the conditional approach which depends upon occurrence of good or bad news. Conditional conservatism reflects the asymmetric timely loss recognition of bad economic news where good news requires higher verification requirement than bad news. This approach is taken since the debate on conservatism has been clouded with wrong and vague definition of conservatism, as it takes the unconditional conservatism similar to conditional conservatism. In fact, the theoretical and empirical benefits of conservatism are deep-rooted in conditional conservatism approach, and the criticism against conservatism principle does not distinguish the two approaches well (Basu, 2009). These issues are also a concern to practitioners inclusive of auditors, financial analysts, investors and government as conservatism becomes the grounded element in reporting of financial statements for nearly a century. The financial information, particularly, earnings, which are then utilized by all the stakeholders and users of financial statements do have impacts on the proper execution of their roles and decision-makings. Concerns over effect of conservatism on audit fees, for example, show the relevance of conservatism issue to auditors and their clients (Gul, Srinidhi \& Shieh, 2002; Lee, Li \& Sami, 2015). The level of conservatism is also found to have an effect on financial ratios and become a factor in the accuracy of financial analysts' forecasts (Givoly \& Hayn, 2002). The importance of conservatism to investors and government alike is already taken care off in the literature (Watts, 2003a), thus showing the significance of the issue to both academics and practitioners. Viewing all the three issues with conservatism, relevance of firms' loss condition, macroeconomic condition and firms' life-cycle stages to conservatism as a measure of earnings quality, in practice, cannot be denied. For example, more and more information on life-cycle stages and effects of loss and macroeconomic conditions are used by industrial players to make decisions particularly in relation to earnings quality (Dichev, Graham, Harvey \& Rajgopal, 2013).

The basis of this study, therefore, is to contribute to existing efforts in examining the issue of conservatism within the results of the examination of loss condition, macroeconomic condition and life-cycle stages. Thus, the centre-stage of this research does not disentangle the main analysis of the three interested variables with the issue of conservatism as an earnings quality measure. Indirectly, the importance, significance and relevance of conservatism principle are revisited with the issue of biasness in mind given the firms' characteristics and specific conditions facing them. The signalling of conservative information of these firms would be assessed, without leaving behind the aims of addressing the issue of conservatism within the premise of earning quality despite the 'exterior' exclusion of the concept from the current underlying bases of accounting recognition, measurement and presentation.

\section{Literature Review}

\subsection{Losses and conservatism}

Researchers studying losses have come up with explanations on how loss occurs (determinants of losses), and how losses affect firms' earnings quality and other variables of interests (effects of losses). Within these studies, there are issues of loss anomaly in earnings-return models represented by negative coefficient of losses, and issue of low informativeness of losses represented by low $\mathrm{R}^{2}$ and earnings response coefficient. 
Studies that look into how loss occurs have pointed to factors including real economic loss of firms (where firms have two options of abandoning the firms or adapting to the firms) (Darrough \& Ye, 2007; Hayn, 1995; Klein \& Marquardt, 2006), investments in intangibles, R\&D and expenditures necessary to bring profitability to businesses (Wu 2016; Darrough \& Ye, 2007; Joos \& Plesko, 2005), non-recurring charges and write-offs (Darrough \& Ye, 2007) and missing book value which relates back to intangibles and capital investments of firms (Burgstahler \& Dichev, 1997; Collins et al., 1999). Losses are also characterized as to whether they are transitory or recurring. Depending on the nature of losses, it is believed that losses give incentives to managers to behave in certain ways. The signalling theory signifies that losses become signal that managers use to convey the quality of their firms' earnings generation. It should be recalled that despite competing explanations of the foundations and components of losses, loss condition is found to have its own quality component by Balkrishna et al. (2007). The only empirical evidence to date examining impact of loss on conservatism provides useful findings on substance of loss where it has components that reflect timely loss recognition as opposed to mere correction of prior period's aggressive reporting. In a similar setting, Darrough and Ye (2007) found that losses are not explained by conservatism. This has empirically answered the issue of reverse causality between losses and conservatism where studies questioned the credibility of timely loss recognition measurement on its actual measurement of conservatism. Prior evidence also suggests that the model of conservatism such as Basu (1997) is actually measuring conditional conservatism and nothing else (Wen Hsin Hsu et al., 2011).

Due to the limited number of literature examining conservatism of loss firms, the literature in distress and other measures of earnings quality is looked at to get further insights of the direct relationship between losses and conservatism. Garcia Lara et al. (2009) is one of two studies linking distress (ex-post) with conservatism. Their evidence shows that failed (bankrupt) firms adopt and signal less conservative accounting treatments than continuing firms in years prior to failure in an attempt to delay bankruptcy. The aggressive accounting signals have been associated with the use of accruals to increase earnings (by using pure accounting manipulation or decrease in cost of goods sold) and the use of loose credit policies to avoid recognizing proper bad debt provision in the attempt to increase sales. In contrast, Wen-Hsin Hsu et al. (2011) provide evidence that financial distress (ex-ante) has a positive association with conservatism, or that the higher the distress the higher the conservatism level. Using two measures of distress, namely option-pricing model of Black Scholes Merton (BSM) (Hillegeist et al., 2004) and Altman (1968)'s Z-score, the level of conservatism using Basu (1997) and non-equity-return based measure of conservatism is higher when the distress level is high. They argue that the high conservatism predominantly arises from accruals components of earnings rather than from cash flow components. This study indirectly show that conservatism may be associated with issue of biasness where the higher the distress (or losses), the higher the conservatism practices.

One of most studied earnings quality in relation to distress conditions is accruals quality. Accruals quality resembles similar characteristics of conservatism from the aspect of recognition as expenses or income where they are decided by managers (discretionary expense or income) rather than by fixed rules. Similarly, conservatism relies on decisions of managers to make speedier or slower loss recognition. This is the main reason for the borrowed application of accruals quality concept within distress situations to conservatism within loss conditions respectively. This part of the section begins with the exploratory study by Smith, Kestel and Robinson (2001) on accounting policy choice of accruals of financially distressed firms. They found that as distress levels go up, the rate of income-increasing accruals do not go up at the same speed. In addition, firms which will fail in the short term (firms in severe distress) tend not to choose income-increasing techniques as frequent as healthy firms. The reason for such behaviour is most likely due to the risk of penalties (and ex-post settling up costs) imposes on them caused by the accounting method chosen. They also found that loss firms which do not subsequently fail in the short term (firms which are expected to turn around their loss situations) tend to signal income-increasing information to gain benefits from the conceal of their distressed condition, and avoidance of technical violation of contracts such as debt contracts. 
DeFond and Jiambalvo (1994) find that earnings quality measured using accruals model decreases in the year prior to bankruptcy-filing. They show that these firms generate positive unexpected accruals (discretionary accruals). However, studies also find contradictory results. DeAngelo et al. (1994) find that firms in distress report large negative accruals to signal to outsiders that the managers of the firms are willing to deal with the distress problems. Saleh and Ahmed (2005) show that firms undergoing debt covenant violation choose to have negative accruals to signal to the government and resource providers that they are in need of financial assistance. Both studies argue that firms signal their problems to obtain concessions from labour unions and subsidies from government (Jones, 1991). Garcia Lara et al. (2009) find that failed firms manage earnings upwards using accruals manipulation in the four years prior to failure if they have low ex-ante probability of failure. However, if probability of failure is high and that they likely exhaust the opportunities for accrual manipulation, they would opt for aggressive real activity manipulations. Having analysed the distress conditions of failed firms with conservatism and accruals quality together, they provide evidence that the failed firms change their accounting treatments to signal more negative accruals in the immediate year prior to bankruptcy. Similar findings like Garcia Lara et al. (2009) are found by Charitou et al. (2007a; 2007b). When distress firms (ex-post) are given qualified audit opinions in the preceding year before failing, these firms choose more income decreasing accruals. This is in contrast with firms who get clean audit report in four to five years prior to bankruptcy. These firms choose more income increasing accruals. In addition, distressed firms which experience top-level management turnover would have more income decreasing accruals in distress periods, consistent with the big-bath exercise explanation.

These mixed results point to several potential explanations. For the upward earnings behaviour, management of financially distressed firms may be concern with short term survival of their firms, caused by motivations (including those of shareholders and institutional investors) to report (and signal) higher earnings in order to avoid debt covenant violations (Dichev \& Skinner, 2002) and probable bankruptcy (Charitou et al., 2007a; 2007b; DeFond \& Jiambalvo, 1994; Garcia Lara et al., 2009). This is considered opportunistic under the contracting theory of accounting policy choice. Alternatively, managers of distressed firms may adjust earnings upward to satisfy their own interests such as avoid management turnover during distressed period, inflate market price to increase compensation based on stock price performance, or to increase compensation from stock-based compensation holdings (Bergstresser \& Philippon, 2006). These motivations fall under the self-interest motivations.

On the other side of the coin, earnings-decreasing behaviour may be caused by both self-interests motivations and 'genuine intentions'. Managers may signal downward adjusted earnings to reduce temporarily the market price so as to increase their own gain from a subsequent management buyout (Perry \& Williams, 1994). Related to the same scenario of change in management or management turnover, new managers may be induced to undertake 'big bath' as part of a wider strategy to blame the previous management for the distressed firm condition (Charito et al., 2007a; DeAngelo et al., 1994; DeFond \& Jiambalvo, 1994). Legitimately, signals of downward earnings could result in management implementing more conservative accounting practices prior to bankruptcy filing to reduce exposure to litigation. This may be done as a result of increased scrutiny by auditors or lenders in order to maintain the credibility of managers in ensuring continuous supply of financial resources from lenders during difficult times (Charitou et al., 2007a). Earnings-decreasing behaviour may also be a result of managers own responsiveness to act on behalf of the shareholders in order to protect the firms from high risk of litigation, and to obtain concessions from various parties for long-term firm survival such as extracting wage concessions from unions or employees or dividend reductions from shareholders (DeAngelo et al., 1994; Saleh $\&$ Ahmed, 2005). Finally, signals of decreases in earnings are also a result of declining economic performance which is done through proper accounting standards' applications of write-downs, impairments, and decreases of short-term accruals. Looking at the only study examining the relationship between losses and conservatism again, Balkrishna et al. (2007) found that loss firms are more conservative than profit firms. The authors argue their results based on the costly contracting theory and prospect theory. Overall, it can be seen that prior literature has used several theories to explain impact of loss and distress 
condition on accruals quality and conservatism and results are mixed. While political costs theory is concern with existence of influence of political position to bargain for favourable treatments by funder/lenders, the reputation management looks at reputation of managers in preserving maintained performance of firms. The agency theory, on the other hand, focuses more on the agent-principal relationship.

In general, all studies come up with mixed findings. Nevertheless, the use of signalling theory as an overarching theory embrace the explanations from other theories well since firms would have more than one reason for signalling any information to outsiders. Based on discussions above and specifically, the inclination of the empirical evidence by prior studies that loss (distress) condition resulted in higher conservatism and higher negative accruals, it is hypothesized that loss firms would signal higher conditional conservatism than profit firms.

$\mathrm{H}_{1}$ : Loss firms are more likely to signal higher level of bad news conservatism information than profit firms.

Charitou et al. (2007b), in discussing about earnings behaviour of firms in financial distress conclude that managers have deliberate choices in signalling either earnings-increasing or earnings-decreasing information which could be driven by managers' self-interests (implying manipulation or signalling), pressure and intervention by shareholders and/or other parties like auditors or creditors (implying costly contracting), or natural declining of economic performance (no manipulation). These three causes of managers' earnings behaviour, however, lack the connection with circumstance of financial distress or losses faced by firms. It is believed that managers of firms facing financial distress or losses would have acted differently during economic crisis and non-crisis. It is also believed that impact of crises on firms depends upon ability of firms to mitigate the default risk associated with the impending recessions.

\subsection{Losses, conservatism and moderation of macroeconomic conditions}

Theoretically and empirically, financial crisis put pressures on firms to convey and signal more positive information to investors to reduce the negative impact of the crisis (Kaminsky \& Schmukler, 1999; Kodres \& Pritsker, 1998). Vichitsarawong et al. (2010) argue that management of firms underwent pressure from crisis are more aggressive in reporting good news than usual. They also delay recognition of bad news because pessimistic investors react more rapidly to bad news than good news. However, recent study by Jenkins et al. (2009) proved that earnings conservatism is higher during economic recession/contraction for three reasons. Firstly, firms are concern with increased accelerated risk of litigation during economic recession. Secondly, investors increase their demands for more conservative accounting because of the increase in uncertainty about future outcomes as they need timely signal of better valuation of assets. Finally, demand for conservative reporting is higher from external funder compared to before and the fact that firms in distress would have higher probability of getting financing from external sources during recession (as opposed to internal sources of financing). Analyses of the two studies show that Jenkins et al. (2009) examine conservatism in the context of business expansion or recession within a single country (i.e. U.S.) and use fixed-effect Basu (1997) model for samples from 1980 to 2003. Vichitsarawong et al. (2010), on the other hand, study conservatism during, pre and post Asian financial crisis, in four different Asian countries, namely Hong Kong, Malaysia, Singapore and Thailand, incorporate dummy variable for expansion economy, and use Basu model by incorporating a post-crisis dummy variable for each country sample from 1995 to 2004 . These similarities and differences between the two studies point to several potential reasons. An initial probe into the matters leads to several other issues such as influence of corporate governance and accounting standards' compliance, the difference or otherwise of the business cycles and financial crises, and the institutional characteristics of Western developed and Asian developing countries. Asian managers, for instance, are seen as less transparent than managers in developed countries like the US due to low demand for private information signals from shareholders. This is also partly caused by Asian firms' governance structures which cause managers to produce financial statements that are less transparent, relative to the US firms although we can 
argue otherwise that less transparent leads to increase information asymmetry between managers and outside shareholders which leads to increased demand in signalling information (Ball, Robin \& Wu, 2003; Claessens, Djankov \& Lang, 2000). Asian managers may occasionally (e.g. during financial crisis) resort to other communication mechanisms to overcome any deficiency in the external reporting process (Eng \& Nabar, 2007). As such, results of Asian studies, particularly Malaysian, may differ from those developed countries' studies. Besides, the different crises examined by both studies motivate this study to analyse all economic crises that have occurred within the study framework.

In this study, the macroeconomic condition is hypothesized to be the moderator variable that affects the relationship between loss condition and conservatism. Moderation occurs when the relationship between two variables depends on a third variable. The third variable which is referred to as the moderated variable or the moderator affects the direction and/or strength of the relationship between the dependent and the independent variables. Based on the theoretical and empirical evidence of the opposite findings of streams of literature (Vichitsarawong et al., (2010) versus Jenkins et al., (2009)) and reviews of prior literature in both areas, macroeconomic condition as an exogenous factor appears to moderately increase the strength of the impact of losses on conservatism. Based on signalling theory as the overarching theory in explaining loss firms behaviour under different economic conditions, it is hypothesized that loss firms during economic crisis would signal higher conditional conservatism than loss firms during non-crisis. This study posits that the loss condition prevails more than crisis condition in determining the signalling of conservative information since loss condition is a factor within the control of firms unlike crisis. Nevertheless, economic crisis does have an effect on conservatism but it only moderates the relationship between loss conditions and conservatism.

$\mathrm{H}_{2}$ : Loss firms under economic crisis are more likely to signal higher level of bad news conservatism information than loss firms under normal economic condition.

Related to loss conditions is the factor of firms' life-cycle stages. Theoretically, life-cycle stages have associations with earnings quality since managers of firms are expected to behave and signal accounting information differently during different life-cycle stages. Empirical evidence to date has shown the association between life-cycle stages and some measures of earnings quality such as the value relevance and accruals quality. However, its relationship with conservatism as one of the main measure of earnings quality remains relatively unexplored with very few studies examining them (Abdullah \& Mohd Saleh, 2014; Ebadi, 2016; Bayati \& Jamshidinavid, 2016). The following section develops the hypotheses related to life-cycle stages within the overall research framework of this study.

\subsection{Life-cycle hypothesis and conservatism}

Life-cycle stages can be defined as distinct and identifiable phases that arise from changes in internal factors such as strategy choices, financial resources and managerial ability, and/or external factors such as competitive environment and macroeconomic factors (Dickinson, 2010). Firms life-cycle has been found to be an important determinant of many corporate decisions (Lester \& Parnell, 1999; Lester et al., 2008; Quinn \& Cameron, 1983; Smith et al., 1985). As a surrogate for firms' economic attributes (Black, 2003), life-cycle stages explain differences in many aspects of firms including, but not limited to, production function, investment opportunities, strategies and risk, financing capabilities and performance. Knowledge of different life-cycle stages provides understanding of firms' historical development and firms' future planning and that different firms at different stages need to be managed differently to be successful (Park \& Chen, 2006). As organizational behaviour differs in different life-cycle stage, the financial reporting behaviour is also expected to vary with stages of organizational life-cycle. Prior research provides evidences that the usefulness of accounting measures and accounting information differ at different life-cycle stages (Anthony \& Ramesh, 1992; Black, 1998; Black, 2003; Park \& Chen, 2006). In other words, firms in different life-cycle stages signal the same information differently. In an unpublished paper by Chen and Huang (2007), accounting conservatism for firms in the start-up and growth 
stages is suggested to be inclined towards unconditional conservatism practice and less of the conditional conservatism. This is done to smooth income. When firms approach declining stage, conditional conservatism becomes stronger to stop the growth-dependent biases caused by unconditional conservatism in the future periods. The total conservatism displays systematic variation over the firm's life-cycle, with a U shape relationship. Previous studies have documented that measures of earnings quality do have their associations with business fundamentals, strategies and financial resources which make up the basis of the life-cycle stages. Accruals have been noted to be heteroscedastic (influenced by external factors) $(\mathrm{Gu}$, Lee \& Rosett, 2005) and have close relationship with many factors inclusive of business fundamentals such as business growth, changes in growth attributes (Khan, 2008; Zhang, 2007), and financial difficulties (Khan, 2008). These correlations show that quality of earnings cannot be secluded from business fundamentals and thus the life-cycle hypothesis. Life-cycle research in effect, is much thorough and comprehensive in reflecting firms' innate factors and in charting the progress of business fundamentals (strategies, financial resources, performance, operating efficiency, operation-related factors) of firms compared to research of business fundamentals in portions or segments. Despite the importance of lifecycle research, there are very few published papers and unpublished working papers examining the lifecycle theory (inclusive of all stages, instead of only growth and mature) and earnings quality.

The published article is the study by Chen et al. (2010b) who note that incorporating life-cycle variables into the accrual models produce better results and reduce type I and type II errors than incorporating a control for corporate performance only. Besides, they are of the view that corporate life-cycle reflects the result of dynamic accounting choice which resembles factors beyond earnings management motivations since it is hardly believed that all managers would share the same motivation and incentives at the same time during different life-cycle stages. This shows that firms signal differently during different lifecycle stages. Chen et al. (2010b) show that introductory and growth firms signal positive accruals compared to mature firms while shakeout and decline firms signal negative accruals in relation to mature firms. The authors relate the results to overestimation of future earnings to obtain external financing for firms in early life-cycle stages while no direct inference is given for the shakeout and decline firms.

Chen and Huang (2007) suggest that during early stages of firms' life cycle, accruals tend to be positive and high in quantity. Its primary role is to match and defer the recognition of revenue, and smooth the earnings. Towards the end of the life-cycle stage, accruals would mostly become negative and accruals' role has changed to increase in conditional conservatism. Similar results are encountered by Liu (2008). Indications from prior research such as Teoh, Wong and Rao (1998) suggest that firms in Initial Public Offering (IPO) years (i.e. early stage of life-cycle) usually signal high positive accruals as an incentive to get external financing. By contrast, firms facing financial distress (i.e. declined stage of life-cycle) would have high negative accruals to signal to outsiders that they are in need of concessions (DeAngelo et al., 1994). In other words, firms in early stage signal positive accruals with the expectation that they are able to generate positive growth while firms in distress (which most likely be in decline stage) signal negative accruals since they are pessimistic about future prospect of their firms. In another unpublished working paper by Adilah Zafirah et al. (2013), mature firms are found to have more volatile accruals and less consistent accounting choices with highest positive change in total accruals and lowest positive change in current accruals, compared to other stage groups. However, mature firms show highest persistence in earnings. The authors conclude the importance of firms' underlying economics as measured by the firms' life-cycle stages as key drivers of accounting quality. Different life-cycle stages influence the derivation of information to be signalled by firms. Using studies examining factors of life-cycle not captured under life-cycle theme, McNichols (2000) argues that firms with higher expected earnings growth signal higher than expected accruals (which indicate poor earnings quality) compared to firms with lower expected earnings growth. Ertimur et al. (2003) reveal that market reaction to revenue surprises is greater than to expense surprises, especially for growth firms, and that the differential price reaction is associated with their relative persistence. Similarly, Lee et al. (2006) argues that firms with higher performance and growth over-report earnings by a larger amount (an indication of low earnings quality) because price responsiveness increases with earnings performance and growth. The results from above studies have so 
far shown signalling of positive information by firms in early stages of life-cycle and signalling of negative information (negative accruals) by firms in later stages of life-cycle. However, Lee et al. (2006) also finds that distressed firms signal greater earnings timeliness for good news and lower earnings timeliness for bad news (which means positive accruals) than healthy firms, and that distressed firms manage earnings towards positive target more frequently than healthy firms. In signalling theory, such reporting behaviour is perhaps caused by the value behind occurrence of loss (and distress) which are perceived by firms to be positive.

The lack of definitive theory relating earnings quality and life-cycle hypothesis makes the search of a suitable explanation remains open. Evidence by studies of factors of life-cycle stages not captured under the theme of life-cycle hypothesis is worth reviewing. Khan and Watts (2009), for instance, argue otherwise that growth firms are more conservative compared to mature firms due to higher information asymmetries of growth firms which demand more conservative reporting. Similarly, Charitou et al. (2011) argues that growth firms may exhibit higher conservatism due to higher ability to show losses compared to mature firms. In these studies, growth firms are viewed as not signalling the true values of their firms but signal information deemed to give them advantage by being in growth stages. This is not against the signalling theoretical explanation since signals are subject to their observability, costs and quality of signallers. In fact, the theory also suggests that signallers will not convey negative signals in an attempt to reduce information asymmetry. Thereby, the negative signals signalled by growth firms, in these cases, indicate other intentions which could be explained by other theories such as political cost theory, and reputation management theory. As signalling is an overarching theory, it does not contradict other theories. Looking back at the life-cycle theory and signalling theory discussed earlier, it appears that the former arguments are more appealing, in that mature firms tend to be less aggressive, more conservative and adopt more income decreasing accruals while growth firms tend to be more aggressive, less conservative and adopt more income increasing accruals. The arguments are also in line with signalling theory. It is therefore, posited that firms' life-cycle stages significantly influence the level of conservatism. Specifically,

$\mathrm{H}_{3}$ : Growth and decline firms are more likely to signal lower level of bad news conservatism information than mature firms;

\section{Methodology/Materials}

\subsection{C_score conservatism model}

As the first step in computing the C_Score, the following modified Basu model is therefore, regressed annually for each year from 1995 to 2010 using Eq. (1) to generate the empirical estimators of $\mu_{\mathrm{i}}$ and $\lambda_{\mathrm{i}}$ $(i=1-4)$. Both of these coefficients are constant across firms, but vary overtime since they are estimated from annual cross-sectional regressions.

$$
\begin{aligned}
\frac{X_{i}}{M V_{i}}=\beta_{1}+\beta_{2} D R_{i}+R_{i}\left(\mu_{1}+\mu_{2} \text { Size }_{i}+\mu_{3} M / B_{i}+\mu_{4} \text { Lev }_{i}\right) \\
\\
+R_{i} * D R_{i}\left(\lambda_{1}+\lambda_{2} \text { Size }_{i}+\lambda_{3} M / B_{i}+\lambda_{4} \text { Lev }_{i}\right)+\left(\delta_{1} \text { Size }_{i}+\delta_{2} M / B_{i}\right. \\
\left.+\delta_{3} \text { Lev }_{i}+\delta_{4} D R_{i} \text { Size }_{i}+\delta_{5} D R_{i} M / B_{i}+\delta_{6} D R_{i} \text { Lev }_{i}\right)+\varepsilon_{i}
\end{aligned}
$$

where, for firm $i$ :

$X_{i} \quad=$ income before extraordinary items (Item WC01551 in Datastream);

$M V_{i} \quad=$ market value of equity at beginning of year (Item MV (Market value) in Datastream);

$R_{i} \quad=$ annual stock returns compounded from monthly returns beginning from the fifth month after the end of the fiscal year (Item UP in Datastream);

$D R_{i} \quad=$ dummy variable, one if $\mathrm{R} \leq 0$, and zero otherwise;

Size $_{i}=$ natural log of market value of equity (Item MV (Market value) in Datastream)

$M / B_{i} \quad=$ market-to-book ratio (Item PTBV in Datastream); 
$\operatorname{Lev}_{i} \quad=$ long-term and short-term debt, scaled by beginning-of-year market value of equity (Item WC03255 in Datastream);

$\varepsilon_{i} \quad=$ error term;

Secondly, the estimators $\mu_{1}$ and $\lambda_{\mathrm{i}}(i=1-4)$ are then substituted in Eq. (2) and Eq. (3) (variables as defined earlier) to estimate the C_Score and G_Score. C_Score shows a firm-year measure of incremental bad news timeliness whereas $G_{-}$S Score measures a firm-year measure of good news timeliness. From the equations, both scores are considered linear functions ${ }^{1}$ of firm-specific characteristics which were described earlier as explaining the variations in firm-year conservatism level (Khan \& Watts, 2009).

$$
\begin{aligned}
& C_{\text {score }}=\beta_{1}=\lambda_{1}+\lambda_{2} \text { Size }_{i}+\lambda_{3} M / B_{i}+\lambda_{4} \text { Lev }_{i} \\
& G_{\text {score }}=\beta_{0}=\mu_{1}+\mu_{1} \text { Size }_{i}+\mu_{1} M / B_{i}+\mu_{1} \text { Lev }_{i}
\end{aligned}
$$

C_Score is the firm-year measure of conservatism indicating incremental bad news timeliness. The G_Score is the good news timeliness. Adding them together produces total bad news timeliness at an individual firm-level. Finally, the computed C_Score is then regressed against variables of interests in the study as a mean to examine the impact of identified factors or determinants on firm-year conservatism. This allows the testing of specific firm-year characteristics such as life-cycle hypothesis and firm's profitability performance to be examined against firm-year level of conservatism, which are not able to be done before due to limitations in Basu's conservatism model. The hypotheses are examined using the following model by regressing $C_{-}$Score against the variables of interest and control variables

$$
\begin{aligned}
C_{-} \text {Score }_{i t}= & \beta_{0}+\beta_{1}+\beta_{1} \text { LOSD }_{i t}+\beta_{2} \text { CRID }_{i t}+\beta_{3} L C G 1_{i t}+\beta_{4} L C G 5_{i t} \\
& +\beta_{5} \text { LOSD }_{i t} * \text { CRID }_{i t}+\beta_{6} \text { CHAU }_{i t}+\beta_{7} \text { CHCEO }_{i t}+\beta_{8} \text { CHCH }_{i t}+\beta_{9} A R T_{i t} \\
& +\beta_{10} \text { AUT }_{i t}+\beta_{11} \text { VOL L }_{i t}+\beta_{12} I N V C_{i t}+\varepsilon_{i t}
\end{aligned}
$$

where:

C_Score ${ }_{i t}=$ the firm-year measure of conservatism, estimated by Equation 3.2;

$\operatorname{LOSD}_{\text {it }}=$ dummy variable, one if negative income (Item WC0551 in Datastream), and zero otherwise;

CRID $_{\text {it }}=$ dummy variable, one if crisis year, and zero otherwise;

LCG1 $1_{\text {it }}=$ dummy variable, one if growth, and zero otherwise;

LCG5 $5_{\text {it }}=$ dummy variable, one if decline stage, and zero otherwise;

$\mathrm{CHAU}_{\text {it }} \quad$ dummy variable, one if change in audit firm (Audit Report in Annual Reports), and zero otherwise;

$\mathrm{CHCEO}_{\text {it }}=$ dummy variable, one if change in CEO (Corporate Information in Annual Reports), and zero otherwise;

$\mathrm{CHCH}_{\mathrm{it}}=$ dummy variable, one if change in Chairman (Corporate Information in Annual Reports), and zero otherwise;

$\mathrm{ART}_{\text {it }}=$ dummy variable, one if qualified audit report (Audit Report in Annual Reports), and zero otherwise;

AUT $_{\text {it }}=$ dummy variable, one if auditor is Big4 (Audit Report in Annual Reports), and zero otherwise;

$\mathrm{VOL}_{\mathrm{it}}=$ volatility, the standard deviation of daily firm-level stock returns in a calendar year (Item UP in Datastream)

$\mathrm{INVC}_{\mathrm{it}} \quad=$ investment cycle, depreciation expense deflated by lagged assets (Item WC01151 and WC02999 in Datastream)

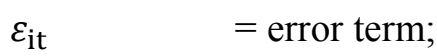

Panel regression estimation methods of pooled OLS, a fixed effect and random effect models are found to be appropriate for analysing relationship between variables of interests and firm-year conservatism of Malaysian firms for the period of 16 years.

\footnotetext{
${ }^{1}$ Studies in accounting conservatism utilizing nonlinear functions are very limited (e.g. Callen, Segal and Hope, 2010) due to inherent difficulties in econometrics modelling (Arellano \& Bonhomme, 2011). Conceptually, the use of panel data analysis can overcome issues of nonlinearity and unobserved heterogeneity simultaneously though with limitations.
} 


\subsection{Variables definition}

This study draws on the influence of the independent variables, LOSD, CRID and LCG on the dependent variable C_Score. The determination of loss firms (LOSD) is based on the occurrence of negative or positive net income before extraordinary items and preferred dividends (see Table 1). The crisis and noncrisis periods that affect Malaysian firms are determined according to empirical justifications found in prior literature. Based on prior studies (Cho \& Yoo, 2011; Dooley \& Hutchison, 2009; Eng, Nabar \& Chng, 2005; Khor \& Kee, 2008), the Asian financial crisis period occurs from year 1997 to year 1998 whereas subprime crisis period occurs from year 2008 to year 2009. Losses occurring during crisis period are considered as losses caused by crisis and vice-versa. The moderation of CRID on the relationship between LOSD and C_Score is assessed using an interaction variable LOSDCRID which is the product of LOSD $\times$ CRID. The life-cycle stage determination is based on the Anthony and Ramesh (1992) procedure which includes growth, capital expenditure, dividend payments and firm age as the determinants of life-cycle stage of firms. The determinants of life-cycle stage are defined in Table 2. The main reason for choosing Anthony and Ramesh (1992)'s life-cycle determination is because all of these determinants are controllable by managers of firms. Since this study relates to financial reporting behaviour of firms, the use of these factors are well suited to test the hypothesis on managers' behaviour. In contrast, measurement by Bens, Nagar and Wong (2002), for instance, uses variable such as market-to-book ratio which is beyond the control of managers as it captures the shareholders' perceptions of the firm's growth options. Besides, many studies in financial reporting have utilized Anthony and Ramesh procedure alone despite other available alternatives (Ahmed \& Jinan, 2011; Park \& Chen, 2006).

Table 1

Definitions of main variables

\begin{tabular}{|c|c|c|c|}
\hline $\begin{array}{c}\text { Variable } \\
\text { name }\end{array}$ & Definition & Measurement & Studies \\
\hline C_Score & $\begin{array}{l}\text { Conservatism (Main- } \\
\text { Dependent) }\end{array}$ & $\begin{array}{l}\text { From Equation 3.2, the following is calculated (as de- } \\
\text { fined earlier): } \\
\text { C_Score }=\beta_{1}+\lambda_{1}+\lambda_{2} \text { Size }_{i}+\lambda_{3} M / B_{i}+\lambda_{4} \text { Lev }_{i}\end{array}$ & $\begin{array}{l}\text { Chi, Liu \& Wang } \\
\text { (2009); } \\
\text { Khan \& Watts (2009) }\end{array}$ \\
\hline LOSD & $\begin{array}{l}\text { Loss condition } \\
\text { (Main- Independent) }\end{array}$ & $\begin{array}{l}\text { Dummy value of } 1 \text { for negative net income before ex- } \\
\text { traordinary items and preferred dividends for firm } i \text { in } \\
\text { year } t ; \text { and } 0 \text { otherwise (Item WC } 01551 \text { in } \\
\text { Datastream) }\end{array}$ & $\begin{array}{l}\text { Garcia Lara et al. } \\
(2009)\end{array}$ \\
\hline CRID & $\begin{array}{l}\text { Macroeconomic con- } \\
\text { dition } \\
\text { (Main- Independent) }\end{array}$ & Crisis years are 1997 to 1998 and 2008 to 2009 & $\begin{array}{l}\text { Khor \& Kee (2008); } \\
\text { Vichitsarawong et al. } \\
(2010)\end{array}$ \\
\hline $\begin{array}{l}\text { LCG1, } \\
\text { LCG3, } \\
\text { LCG5 }\end{array}$ & $\begin{array}{l}\text { Life-cycle stage } \\
\text { (Main-Independent) }\end{array}$ & $\begin{array}{l}\text { Growth, mature and decline stages are defined using } \\
\text { sales growth, capital expenditure, dividend payment } \\
\text { and age. } \\
\text { LCG1 = Growth firms } \\
\text { LCG3 = Mature firms } \\
\text { LCG5 = Decline firms }\end{array}$ & $\begin{array}{l}\text { Anthony \& Ramesh } \\
\text { (1992) }\end{array}$ \\
\hline
\end{tabular}

In addition, this procedure includes firm age as the non-financial indicator of life-cycle unlike other wellknown measurements such as those proposed by Dickinson (2011) and DeAngelo et al. (2006) which are based purely on financial indicators. However, the use of firm age alone is not justified (Yan \& Zhao, 2010) because life-cycle stage reflects changes in not only age of firms but also the economic characteristics of firms. There are situations where firms do not follow the normal path of life-cycle. For instance, some firms may become decline firms right after growth stage while most others become mature firms. 
The abnormal route of life-cycle for some firms may not be able to be captured using firm age variable only.

Table 2

Determinants of life-cycle stages

\begin{tabular}{|c|c|}
\hline $\begin{array}{l}\text { Life-cycle determi- } \\
\text { nants }\end{array}$ & Definition \\
\hline \multirow[t]{2}{*}{ Growth } & $\mathrm{SG}_{t}=\frac{\left(\text { Sales }_{\mathrm{t}}-\text { Sales }_{t-1}\right)}{\text { Sales }_{t-1}} * 100$ \\
\hline & $\begin{array}{l}\text { Percent sales growth in year } t \\
\text { Net sales in year } t \text {, year } t-1 \text { (Item WC } 01001 \text { in Datastream) }\end{array}$ \\
\hline \multirow[t]{2}{*}{ Capital expenditure } & $\mathrm{CEV}_{t}=\frac{\mathrm{CE}_{\mathrm{t}}}{\mathrm{VALUE}_{t}} * 100$ \\
\hline & $\begin{array}{l}\mathrm{CEV}_{\mathrm{t}}: \quad \text { Capital expenditure as a percentage of total value of the firm in year } t \\
\mathrm{CE}_{\mathrm{t}}: \quad \text { Capital expenditure in year } t \text { (Item WC } 04601 \text { in Datastream) } \\
\text { VALUE }: \text { Market value of equity plus book value of long-term debt at the end of the year } t \\
\text { (Item MV and WC03251 Datastream) }\end{array}$ \\
\hline \multirow[t]{2}{*}{ Dividend payment } & $\mathrm{DP}_{t}=\frac{\mathrm{DIV}_{\mathrm{t}}}{\mathrm{IBED}_{t}} * 100$ \\
\hline & $\begin{array}{ll}\mathrm{DP}_{\mathrm{t}}: & \text { Annual dividend as a percentage of income in year } t \\
\mathrm{DIV}_{\mathrm{t}}: & \text { Common dividends in year } t \text { (Item WC05376 in Datastream) } \\
\text { IBED }_{\mathrm{t}}: & \text { Income before extraordinary items and discontinued operations in year } \mathrm{r}_{\mathrm{t}} \text { (Item } \\
& \text { WC01551 in Datastream) }\end{array}$ \\
\hline Age & $\begin{array}{l}\text { Difference between the current year and the year in which the business was originally formed. } \\
\text { *A comparison is also made, where appropriate, against the age definition based on the difference } \\
\text { between the current year and the IPO year in which the business was originally listed. Use of age } \\
\text { based on IPO date has been adopted by DeAngelo et al. (2010). }\end{array}$ \\
\hline
\end{tabular}

Other life-cycle determinants that have been used in prior research include earned/contributed capital mix explanation. This measurement of life-cycle stage proposed by DeAngelo et al. (2006) is based on patterns of firms' dividend distribution. Firms which are self-financing (with high ratio of Retained Earnings/Total Earnings and Retained Earnings/Total Assets) are mature firms whereas firms which are reliant on external capital (with low ratio of Retained Earnings/Total Earnings and Retained Earnings/Total Assets) are growth firms. Although this explanation is convincing, the suitability of only dividend distribution (without considering other factors) for determining life-cycle stage of firms in Malaysia could be challenged by the fact that Malaysian firms have unstable dividend policy due to high sensitivity to earnings change and low dividend smoothing policy (Pandey, 2003). Alternatively, researchers have also used Dickinson's (2011) measure of life-cycle stage using cash flows from operating, investing and financing activities. This study does not use this measurement because of the limited data availability for early years of the sample of this study ${ }^{2}$. This could be attributed by the late mandatory application of cash flow statements by companies in Malaysia. The introduction of cash flow statements starts in 1996 with the adoption of IAS7 (Revised). During this time, financial reporting was mainly governed by private professional bodies and that accounting standards are not yet made mandatory until the enactment of the Financial Reporting Act 1997 in 1997. Few years later, the Malaysian Accounting Standards Board introduce MASB 5 Cash Flow Statements which supersedes IAS7 (Revised) effective 1 July 1999. The use of Dickinson's measure, therefore, would affect the reliability of the life-cycle stage determination as not all firms prepare cash flow statements during those years. The model studied also incorporates some of control variables related to data characteristics, besides the control variables of the model in question. Based on previous literature, the following variables have been incorporated in studies that examine accounting policy choice of firms under distress which are audit qualification (Charitou et al.,

${ }^{2}$ For 1995, only 54 firm-observations for cash flow from operating, investing and financing data are available. Similarly, for 1996 only 225 observations are available. 
2007a; DeFond \& Jiambalvo, 1994; Saleh \& Ahmed, 2005), change in management either new executive or managing director (Charitou et al., 2007a; DeAngelo et al., 1994; Saleh \& Ahmed, 2005), and auditor type (Francis \& Krishnan, 1999). Other variables controlled in prior studies, namely firm performance (Kasznik, 1999; Saleh \& Ahmed, 2005), firm size (Kim, Liu \& Rhee, 2003; Saleh \& Ahmed, 2005), leverage (Saleh \& Ahmed, 2005; Watts, 2003a), and liquidity (Saleh \& Ahmed, 2005) are already incorporated inside the main variables.

Table 3

Definitions of control variables

\begin{tabular}{|c|c|c|c|}
\hline Variable name & Definition & Measurement & $\begin{array}{r}\text { Studies } \\
\end{array}$ \\
\hline $\mathrm{CHCH}$ & Change in Chairman & $\begin{array}{l}\text { Dummy value of } 1 \text { for change in } \\
\text { Chairman; and } 0 \text { otherwise }\end{array}$ & $\begin{array}{l}\text { Charitou et al. (2007a); } \\
\text { DeAngelo et al. (1994); } \\
\text { Saleh \& Ahmed (2005) }\end{array}$ \\
\hline CHCEO & $\begin{array}{l}\text { Change in Chief Executive } \\
\text { Officer (CEO) }\end{array}$ & $\begin{array}{l}\text { Dummy value of } 1 \text { for change in } \\
\text { CEO; and } 0 \text { otherwise }\end{array}$ & $\begin{array}{l}\text { Charitou et al. (2007a); } \\
\text { DeAngelo et al. (1994); } \\
\text { Saleh \& Ahmed (2005) }\end{array}$ \\
\hline CHAU & Change in Audit Firm & $\begin{array}{l}\text { Dummy value of } 1 \text { for change in } \\
\text { audit firm; and } 0 \text { otherwise }\end{array}$ & Saleh \& Ahmed (2005) \\
\hline ART & Audit Report Type & $\begin{array}{l}\text { Dummy value of } 1 \text { for qualified } \\
\text { audit opinion; and } 0 \text { otherwise }\end{array}$ & $\begin{array}{l}\text { Charitou et al. (2007a); } \\
\text { DeFond \& Jiambalvo (1994); } \\
\text { Saleh \& Ahmed (2005) }\end{array}$ \\
\hline AUT & Auditor Type & $\begin{array}{l}\text { Dummy value of } 1 \text { for Big- } 4 \text { audi- } \\
\text { tors; and } 0 \text { otherwise }\end{array}$ & Francis \& Krishnan (1999) \\
\hline VOL & Volatility & $\begin{array}{l}\text { Standard deviation of daily firm- } \\
\text { level stock returns in a calendar } \\
\text { year }\end{array}$ & $\begin{array}{l}\text { Chi, Liu \& Wang (2009); } \\
\text { Khan \& Watts (2009) }\end{array}$ \\
\hline INVC & Investment Cycle & $\begin{array}{l}\text { Depreciation expense deflated by } \\
\text { lagged assets }\end{array}$ & $\begin{array}{l}\text { Chi, Liu \& Wang (2009); } \\
\text { Khan \& Watts (2009) }\end{array}$ \\
\hline
\end{tabular}

\subsection{Sample}

Data from 1995 to 2010 for all Malaysian firms (excluding banks and financial institutions) downloadable from Datastream is used for this analysis. Malaysian data is chosen due to the gap in existing literature and the fact that Malaysian economy is different from the other developed economies which implies the cautiousness one must take in generalizing western-based findings to developing economies such as Malaysia. The significant institutional differences between developed and developing economies, and the growing economic significance of countries with relationship-based economies such as Malaysia have been found to play important roles in studies done within the context of local developing economy. The issue of earnings quality is particularly important in emerging countries like Malaysia, where financial statement users and the capital market generally do not have adequate technical knowledge and a sophisticated market, respectively, thus making users unable to gauge the manipulated earnings. Further, in Malaysia the unique features of business enterprises such as heavy debt burden, less transparency and governance, closely held ownership structure (Claessens et al., 2000), and influence of politics in a number of publicly held firms (Gomez \& Jomo, 1997; Johnson \& Mitton, 2003) result in different levels of contracting and political costs, which may not be found in the developed western countries. Sample years from 1995 to 2010 are chosen since these years are the years that show significant developments of Malaysian listed firms quantitatively. Company specific data for most listed firms prior to 1995 was not easily accessed. In fact, hardcopy documents were not even available for many companies. Furthermore, many of the listed companies prior to 1995 were no longer listed in Bursa Malaysia due to various reasons. This scenario, therefore, limits the analysis of this study to firms listed on the stock exchange from 1995 onwards. The nature of the life-cycle variable needs longer life-span of companies to assess the life-cycle stage of firms. As a result, the sample years extend to 2010 to allow the analysis of the impact of life-cycle stage on firm year conservatism level be done with reliability and validity. The 16-year sample period is also chosen due to the coverage of two financial crises that Malaysian firms were facing, namely the 1997 Asian financial crisis and the 2008/9 subprime-credit crisis. Although the two crises are different by their names, both crises are actually similar (Khor \& Kee, 2008). The inclusion of both in 
the analysis provides a comparative view of the relationship between both crises with conservatism level. The sample period ends in 2010 for the main reason that this is the final year in which partial convergence to IFRS takes place before IFRSs are mandated to be fully converged starting 1 January 2012. The year 2011 is not chosen in the sample since in 2011, firms are allowed to early adopt all standards that have not yet been made compulsory. Full convergence to IFRS for all non-private entities (or firms) means that those firms are now following the new accounting standards in preparing their financial statements. As a brief note, promulgation of IFRS worldwide implicate that firms have a commitment to increase disclosure in order to tighten up accounting treatments of financial information. The reporting and disclosure based on the IFRS have always been assumed to bear higher accounting and disclosure requirement compared to other accounting standards such as locally produced standards (Leuz \& Verrecchia, 2000). IFRSs are explicitly considered as principles-based standards (Carmona \& Trombetta, 2008). In relation to Malaysia, similar assumption applies. The removal of conservatism principle from the Conceptual Framework of IASB which has subsequently affected that new IFRSs provisions made effective 2012 (in Malaysia) onwards, shows that the financial reports, in particular, the valuation of earnings, and other elements of financial statements (such as assets, liabilities, equities, income and expenses), are considered not bearing the conservatism values (Macve, 2015; Smith, Smith \& Burrowes, 2013). Therefore, this study limits its sample years to only 2010 based on the above issues. Extension of sample period to 2011 and beyond would jeopardise the findings of the study as the measurement of earnings during full convergence and partial convergence would be materially different. This sample period determination has taken into account the issue of various earnings calculation within the Statement of Profits and Losses and Other Comprehensive Income or previously known as Income Statement.

\section{Results and Findings}

First, all sample firm data is run on a pooled regression basis. Secondly, the random effect panel is used to compare the results between pooled and random effect regressions. The LM-Breusch Pagan test reveals that random effect is preferred to pooled-OLS model with a $0.000 \mathrm{p}$-value, thus rejecting the null hypothesis that there is no variance of the error term. In other words, the test reveals that there is heterogeneity (difference) across individual firms in the sample which warrants the use of panel data analysis instead of pooled regression analysis. The next step is to test this random effect model against fixed effect model by performing the Hausman-test. The results shows a $0.000 \mathrm{p}$-value (significant at $5 \%$ level), leading to the rejection of the null hypothesis that there is no correlation between the firm-specific error component and the right hand side (independent) variables of the regression model. Thus, fixed effect estimation is preferred for this analysis as shown in the third column. Besides, the fixed effects estimation uses within variation in the data that allows for endogeneity of the regressors, and it is more appropriate when focusing on specific set of individual samples. The VIF test result of average 1.16 rules out the presence of multicollinearity in the estimation model. However, the Modified Wald test indicates a significant presence of heteroskedasticity at less than $1 \%$ significance level $(0.000 \mathrm{p}$-value $)$ in the regression performed. Similarly, the serial correlation test shows a problem of serial correlation at less than $1 \%$ significance level ( $0.000 \mathrm{p}$-value). Therefore, the use of robust fixed effects model controlling for time effect (results in the third column) is appropriate in addressing the problems of heteroskedasticity and serial correlation in the model. The result of robust fixed effects improves significantly from the normal fixed effect model as loss condition (LOSD) is found to be positively affecting the bad news conservatism level (C_Score) at 10\% significance level. This means that the higher the loss condition, the greater the signal for conservatism would be, thus accepting the hypothesis 1 (H1) that loss firms are more conservative than profit firms. This result is consistent with Balkrishna et al. (2007) where conservatism of loss firms is not associated with simply temporary loss reversals but the actual earnings behaviour of signalling the quality of earnings of those firms. In essence, loss firms signal more conservative earnings in-

formation, perhaps due to less expectation of future value of firms. Again, from another viewpoint, the results may highlight the issue of biasness of conservatism, where losses lead to more conservative earnings. 
The result is not in line with the result of crisis condition (CRID) as the coefficient is not significant under the robust fixed effect model. This means that crisis condition has no significant relationship with conservatism. In other words, conservatism is not affected by the occurrence of economic crisis. However, the significance of LOSDCRID (at 5\% level) indicates that crisis condition positively moderates the relationship between loss condition and conservatism level. In other words, crisis years strengthen the conservatism level for loss firms which were not significant previously, thus accepting hypothesis 2 $\left(\mathrm{H}_{2}\right)$. This is in line with prior studies by Jenkins et al. (2009), Saleh and Ahmed (2005) and Chia, Lapsley and Lee (2007) which found significantly higher bad news conservatism (using Basu 1997) and income decreasing accruals during economic contractions and financial crisis. From signalling theory point of view, it appears that loss firms signal earnings more conservatively during crisis due to expectation of lower future value of firms during crisis compared to during non-crisis. When looking into the issue of biasness tagged along with conservatism measure, it is difficult to conclude that crisis alone leads to biasness as it is almost clear that biasness exists when firms are in loss condition.

\section{Table 4}

Results of Eq. (4) for regressing C Score on independent variables on total sample

\begin{tabular}{|c|c|c|c|c|c|c|}
\hline \multicolumn{7}{|l|}{ Dependent variable is $C$ _Score $(n=8,431)$} \\
\hline \multirow[t]{2}{*}{ Independent Variable } & \multicolumn{2}{|c|}{ Panel-Fixed Effects } & \multicolumn{2}{|c|}{$\begin{array}{c}\text { Fixed Model with Time } \\
\text { Effects }\end{array}$} & \multicolumn{2}{|c|}{$\begin{array}{l}\text { Fixed Model with Time } \\
\text { Effect (Robust) }\end{array}$} \\
\hline & Coefficients & t-stats & Coefficients & t-stats & Coefficients & t-stats \\
\hline $\mathrm{C}$ & 0.218 & $4.16 * * *$ & 0.570 & $3.11 * * *$ & 0.570 & $8.93 * * *$ \\
\hline LOSD & 0.075 & 1.46 & 0.106 & $2.08 * *$ & 0.106 & $1.83 *$ \\
\hline CRID & 0.178 & $3.83 * * *$ & -0.024 & -0.12 & -0.024 & -0.47 \\
\hline LOSD CRID & 0.154 & $1.74^{*}$ & 0.167 & $1.91 *$ & 0.167 & $2.09 * *$ \\
\hline LCG1 & -0.314 & $-5.17 * * *$ & -0.298 & $-4.85 * * *$ & -0.298 & $-4.72 * * *$ \\
\hline LCG5 & -0.003 & -0.04 & -0.054 & -0.93 & -0.054 & -1.13 \\
\hline CHAU & -0.026 & -0.80 & 0.015 & 0.46 & 0.015 & 0.40 \\
\hline CHCEO & 0.158 & $2.88 * * *$ & 0.131 & $2.44 * *$ & 0.131 & $2.08 * *$ \\
\hline $\mathrm{CHCH}$ & 0.072 & 1.29 & 0.064 & 1.18 & 0.064 & 0.96 \\
\hline ART & 0.160 & $2.66 * * *$ & 0.067 & 1.08 & 0.067 & 1.03 \\
\hline AUT & -0.201 & $-2.84 * * *$ & -0.160 & $-2.29 * *$ & -0.160 & $-2.55 * *$ \\
\hline VOL & 0.000 & 0.07 & 0.000 & 0.15 & 0.000 & 0.33 \\
\hline INVC & 0.112 & 0.77 & 0.100 & 0.71 & 0.100 & 1.36 \\
\hline \multicolumn{7}{|l|}{ INDS (not reported) } \\
\hline Adjusted Rsq & 0.0153 & - & 0.0698 & - & 0.0698 & - \\
\hline Breush Pagan LM test (p-value) & - & 0.0000 & - & - & - & - \\
\hline Hausman test (p-value) & - & 0.0000 & - & - & - & - \\
\hline VIF & 1.16 & - & - & - & - & - \\
\hline $\begin{array}{l}\text { Modified Wald Test for: Heteroskedasticity } \\
\text { (p-value) }\end{array}$ & - & 0.0000 & - & - & - & - \\
\hline $\begin{array}{l}\text { Serial Correlation } \\
\text { (F-value) }\end{array}$ & - & $\begin{array}{l}0.0319 \\
(0.0000)\end{array}$ & - & - & - & - \\
\hline
\end{tabular}

Note: C_Score is the firm-year measure of conservatism, estimated by Equation 3.2; G_Score is the firm year measure of conservatism, estimated by Equation 3.3; LOSD is dummy variable, one if negative income (Item WC0551 in Datastream), and zero otherwise; CRID is dummy variable, one if crisis year, and zero otherwise; LOSDCRID is interaction variable between LOSD and CRID; LCG1 is dummy variable, one if growth, and zero otherwise; LCG3 is dummy variable, one if mature, and zero otherwise; LCG5 is dummy variable, one if decline, and zero otherwise; CHAU is dummy variable, one if change in audit firm, and zero otherwise; $\mathrm{CHCEO}$ is dummy variable, one if change in $\mathrm{CEO}$, and zero otherwise; $\mathrm{CHCH}$ is dummy variable, one if change in Chairman, and zero otherwise; ART is dummy variable, one if qualified audit report, and zero otherwise; AUT is dummy variable, one if auditor is Big4, and zero otherwise; VOL is volatility, the standard deviation of daily firm-level stock returns in a calendar year (Item UP in Datastream). INVC is investment cycle, the depreciation expense (Item WC01151 in Datastream), scaled by lagged total assets (Item WC02999 in Datastream); ***,*** indicate significantly different from zero at the 0.10, 0.05 and 0.01 level (two-tailed), respectively.

The significance of LOSDCRID could also be associated with the avoidance of increasing risk of litigation faced by loss firms during crisis. As one of the conservatism explanation is litigation, it is accepted that conservatism play a role in reducing the risk of litigation due to higher scrutiny and monitoring by stakeholders especially in the presence of contracts with shareholders and debt holders. The contracting explanation makes the issue more serious. It is also a fact that loss firms would exercise more conservative reporting due to their needs to apply for external financing as opposed to internal financing (Saleh 
\& Ahmed, 2005). In terms of signalling explanation, investors would demand more conservative reporting by firms and timely signal of better valuation of assets due to the increase in uncertainty about future outcomes. It appears that loss conditions in non-crisis periods do not require conservatism as highly as would be required by these firms in crisis years. The significantly negative coefficient of LCG1 (growth firms) indicates that growth firms signal less conservative earnings compared to mature firms. Along the same line, declined firms (LCG5) are also found to signal less conservative information compared to mature firms although the coefficient is not significant. The results support hypothesis 3 (H3) which states that mature firms signal higher level of bad news conservatism than growth and decline firms. The descriptive result shows that conservatism levels differ significantly among all three life-cycle stages which is in line with all studies examining life-cycle stages and earnings quality despite different directions found for each stage (Adilah Zafirah et al. 2013; Charitou et al. 2011; Chen et al. 2010b), thus upholding the theoretical foundations of life-cycle stages and their impacts on earnings quality. The results are in line with Chen and Huang (2007) and Liu (2008), and are partially similar to Chen et al. (2010b) which states that growth firms tend to have higher positive accruals compared to mature firms. However, the authors found that decline firms have more negative accruals than other life-cycle stages. The findings are also partially supported by Charitou et al. (2011) which state that decline firms are more conservative (represented by high negative accruals) compared to mature firms although Charitou et al. (2011) also state that growth firms are more conservative. In relation to the control variables, only CHCEO and AUT are significant in the model. This confirms that changes in management of firms particularly the CEO increase the conservatism level. This is in line with the Big Bath theory where new CEO taking over the company would charge higher negative provisions and signal accordingly (thus increasing the conservatism) with the intention to blame prior management (Charitou et al., 2007a). On the auditor type, it is expected that the expertise and reputation of Big-4 auditors lead to higher conservatism practices of the client firms. Alternatively, it could be said that Big-4 auditors, given their market share, are able to choose less risky firms as their clients (Gul et al., 2002).

\section{Conclusion}

This study shows that loss firms signal significantly more bad news conservative information than profit firms as shown by hypothesis 1 . It indicates that loss conditions do have its own component in conservatism model that reflect conditional conservatism or asymmetric timely loss recognition of economic losses. The theoretical views in opportunistic versus signalling behaviour, and self-motivations explanations reflect that losses are not merely reversal of overly optimistic accounting recognition in prior years. The contributing explanations from costly contracting theory and prospect theory strengthen the general proposition that losses have values in which their signals indicate quality of reporting, specifically the quality of earnings. This result has directly answered the first research question that the earnings quality of loss firms measured using the conditional conservatism measure differs from profit firms. When the relationship between loss condition and conservatism is moderated by the economic crisis, loss firms maintain the signalling of significantly higher level of bad news conservatism during crisis compared to loss firms during non-crisis period. The results support hypothesis 2 . This suggests that economic crisis play a role in firms signalling of conservative earnings information by loss firms. Internally, firms would encounter opportunistic and self-motivations interests versus signalling behaviour. But externally, the explanations of politically based information regulation theory, and environmental determinism theory state that macroeconomic conditions interact with internal factors to produce outcome which are signalled in terms of earnings quality, namely conservatism. During crisis, firms are predicted to increase their earnings quality through higher signalling of conservatism information and the loss condition already faced by firms induces further the quality of earnings. The results answer the second research objective by stating that the quality of earnings of loss firms undergoing bad macroeconomic condition measured using the conditional conservatism measure differs from loss firms undergoing bad macroeconomic condition. Both hypothesis 1 and 2 results fulfill the first objective of the study by examining the relationship between firms' loss condition and conditional conservatism as an earnings quality measure as well as the moderation of macroeconomic condition on the relationship. This study proceeds with the 
testing of hypothesis 3 which successfully answer the second research objective of whether the quality of earnings measured using the conditional conservatism measure vary at different firms' life-cycle stage. Growth and decline firms are found to signal lower level of bad news conservatism than mature firms (hypothesis 3). Looking back at the life-cycle theory and the explanations on opportunistic, signalling behaviour and self-motivations, life-cycle stages are found to give significant influence to firms' conservatism level through the characteristics of firms that make up the different life-cycle stages. Growth firms which are characterised as young, and having more investment opportunities, less assets-in-place, huge capital expenditure, high sales growth, and less cash were found to signal less conservatively compared to mature firms which take the opposites of growth firms' characteristics.

\section{Acknowledgement}

This research work is supported by the research grant, Geran UPM (2017), provided by University Putra Malaysia

\section{References}

Abdullah, A.A., \& Saleh, N.M. (2014). Impact of firms' life-cycle on conservatism: the Malaysian evidence. Procedia - Social and Behavioral Sciences, 145, 18 - 28.

Adilah Zafirah, M.S., Hsu, G., \& Wyatt, A. (2013). The relation between firm growth and accounting quality: A test of the life cycle hypothesis. British Accounting and Finance Association Annual Conference 2013. Nottingham Business School, United Kingdom.

Ahmed, K., \& Jinan, M. (2011). The association between research and development expenditure and firm performance: testing a life cycle hypothesis. International Journal of Accounting, Auditing and Performance Evaluation, 7(4), 267-286.

Altman, E. I. (1968). Financial ratios, discriminant analysis and the prediction of corporate bankruptcy. The journal of finance, 23(4), 589-609.

Anthony, J.H., \& Ramesh, K. (1992). Association between accounting performance measures and stock prices. Journal of Accounting \& Economics, 15, 203-227.

Balakrishnan, K. (2010). Credit market conditions and economy-wide consequences of financial reporting quality. Ph.D., New York University, Graduate School of Business Administration, United States -- New York.

Balkrishna, H., Coulton, J.J., \& Taylor, S. (2007). Accounting losses and earnings conservatism: evidence from Australian Generally Accepted Accounting Principles. Accouting and Finance, 47, 381-400.

Ball, R., Robin, A., \& Wu, J.S. (2003). Incentives versus standards: properties of accounting income in four East Asian countries. Journal of Accounting and Economics, 36(1-3), 235-270.

Bayati, M., \& Jamshidinavid, B. (2016). Study of the influence of different levels of life-cycle on asymmetric timeliness of profit in the accepted corporations in the Tehran stock exchange. International Business Management, 10(3), 6214-6219

Basu, S. (1997). The conservatism principle and the asymmetric timeliness of earnings1. Journal of Accounting and Economics, 24(1), 3-37.

Basu, S. (2009). Conservatism research: Historical development and future prospects. China Journal of Accounting Research, 2(1), 1-20.

Bens, D.A., Nagar, V., \& Wong, M.H.F. (2002). Real investment implications of employee stock option exercises. Journal of Accounting Research, 40(2), 359-393.

Bergstresser, D., \& Philippon, T. (2006). CEO incentives and earnings management. Journal of financial economics, 80(3), 511-529.

Bertomeu, J., \& Magee, R.P. (2011). From low-quality reporting to financial crises: Politics of disclosure regulation along the economic cycle. Journal of Accounting and Economics, 52(2-3), 209-227.

Black, E.L. (1998). Life-cycle impacts on the incremental value-relevance of earnings and cash flow measures. Journal of Financial Statement Analysis 4(1), 40-56.

Black, E.L. (2003). Usefulness of financial statement components in valuation: An examination of start-up and growth firms. Venture Capital, 5(1), 47-69. 
Burgstahler, D., Jiambalvo, J., \& Noreen, E. (1989). Changes in the probability of bankruptcy and equity value. Journal of Accounting and Economics, 11(2-3), 207-224.

Burgstahler, D.C., \& Dichev, I.D. (1997). Earnings, adaptation and firm value. The Accounting Review, 72(2), 187-215.

Carmona, S., \& Trombetta, M. (2008). On the global acceptance of IAS/IFRS accounting standards: The logic and implications of the principles-based system. Journal of Accounting and Public Policy, 27(6), 455-461.

Charitou, A., Lambertides, N., \& Trigeorgis, L. (2007a). Earnings behaviour of financially distressed firms: The role of institutional ownership. Abacus, 43(3), 271-296.

Charitou A., Lambertidesm N., \& Trigeorgis, L. (2007b). Managerial discretion in distressed firms. British Accounting Review, 39(4), 323-346.

Charitou, A., Lambertides, N., \& Trigeorgis, L. (2011). Distress risk, growth and earnings quality. Abacus, 47(2), 158-181.

Chen, N.-F., Roll, R., \& Ross, S.A. (1986). Economic forces and the stock market. Journal of Business 59(3), 383-403.

Chen, X., \& Huang, D. (2007). Corporate life-cycle, accrual characteristics and accounting conservatism. Working paper. Southwestern University of Finance \& Economics.

Chen, X., Yang, W., \& Huang, D. (2010b). Corporate life-cycle and the accrual model: an empirical study based on Chinese listed companies. Frontiers of Business Research in China, 4(3), 580-607.

Chi, W., Liu, C., \& Wang, T. (2009). What affects accounting conservatism: A corporate governance perspective. Journal of Contemporary Accounting \& Economics, 5(1), 47-59.

Chia, Y.M., Lapsley, I., \& Lee, H.-W. (2007). Choice of auditors and earnings management during the Asian financial crisis. Managerial Auditing Journal, 22(2), 177-196.

Cho, J., \& Yoo, B.H. (2011). The Korean stock market volatility during the currency crisis and the credit crisis. Japan and the World Economy. 23(4), 246-252.

Claessens, S., Djankov, S., \& Lang, L. H. (2000). The separation of ownership and control in East Asian corporations. Journal of financial Economics, 58(1-2), 81-112.

Collins, D.W., Pincus, M., \& Xie, H. (1999). Equity valuation and negative earnings: The role of book value of equity. The Accounting Review, 74(1), 29-61.

Connelly, B.L., Certo, S.T., Ireland, R.D., \& Reutzel, C.R. (2011). Signaling theory: A review and assessment. Journal of Management, 37(1), 39-67.

Darrough, M., \& Ye, J. (2007). Valuation of loss firms in a knowledge-based economy. Review of Accounting Studies, 12(1), 61-93.

DeAngelo, H., DeAngelo, L., \& Skinner, D.J. (1994). Accounting choice in troubled companies. Journal of Accounting \& Economics, 17, 113-143.

DeAngelo, H., DeAngelo, L., \& Stulz, R. (2006). Dividend policy and the earned/contributed capital mix: A test of the life-cycle theory. Journal of Financial Economics, 81, 227-254.

DeAngelo, H., DeAngelo, L., \& Stulz, R.M. (2010). Seasoned equity offerings, market timing, and the corporate lifecycle. Journal of Financial Economics, 95(3), 275-295.

Dechow, P., Ge, W., \&Schrand, C. (2010). Understanding earnings quality: A review of the proxies, their determinants and their consequences. Journal of Accounting and Economics, 50(2-3), 344-401.

DeFond, M., \& Jiambalvo, J. (1994). Debt covenant violations and manipulation of accruals. Journal of Accounting \& Economics, 17(1\&2).

Dichev, I.D., Graham, J.R., Harvey, C.R., \& Rajgopal, S. (2013). Earnings quality: Evidence from the field. Journal of Accounting and Economics. 56 (2-3, Supplement1),1-33.

Dichev, I.D., \& Skinner, D. (2002). Large sample evidence on the debt covenant hypothesis. Journal of Accounting Research, 40(4), 1091-1123.

Dickinson, V. (2010). Cash flow patterns as a proxy for firm life cycle. Working paper. University of Florida.

Dickinson, V. (2011). Cash flow patterns as a proxy for firm life cycle. The Accounting Review, 86(6), 19691994.

Ebadi, T. (2016). The effect of corporate life cycle on the accounting conservatism. Scinzer Journal of Accounting and Management, 2(1), 1-11 
Eng, L.L., \& Nabar, S. (2007). Loan loss provisions by banks in Hong Kong, Malaysia and Singapore. Journal of International Financial Management and Accounting, 18(1), 18-38.

Francis, J., Olsson, P., \& Schipper, K. (2008b). Earnings quality. Massachussets: Now Publishers Inc.

Francis, J.R., \& Krishnan, J. (1999). Accounting accruals and auditor reporting conservatism. Contemporary Accounting Research, 16(1), 135-165.

Garcia Lara, J.M., Garcia Osma, B., \& Neophytou, E. (2009). Earnings quality in ex-post failed firms. Accounting \& Business Research, 39(2), 119-138.

Givoly, D., \& Hayn, C. (2000). The changing time-series properties of earnings, cash flows and accruals: Has financial reporting become more conservative? Journal of Accounting and Economics, 29(3), 287-320.

Gomez, E., \& Jomo, K.S. (1997). Malaysia's Political Economy: Politics, Patronage and Profits. Cambridge: Cambridge University Press.

Gu, Z., Lee, C.W.J., \& Rosett, J.G. (2005). What determines the variability of accounting accruals? Review of Quantitative Finance and Accounting, 24(3), 313-334.

Gu, F., \& Li, J.Q. (2003). Disclosure of innovation activities by high-technology firms. Asia-Pacific Journal of Accounting \& Economics, 10, 143-172.

Gul, F.A., Srinidhi, B., \& Shieh, T. (2002). The Asian financial crisis, accounting conservatism and audit fees: Evidence from Hong Kong. SSRN eLibrary.

Hayn, C. (1995). The information content of losses. Journal of Accounting and Economics, 20(2), 125-153.

Hillegeist, S., Keating, E., Cram, D., \& Lundstedt, K. (2004). Assessing the probability of bankruptcy. Review of Accounting Studies, 9(1), 5-34.

Jenkins, D.S., Kane, G.D., \& Velury, U. (2009). Earnings conservatism and value relevance across the business cycle. Journal of Business Finance and Accounting, 36(9\&10), 1041-1058.

Johnson, S., \& Mitton, T. (2003). Cronyism and capital controls: evidence from Malaysia. Journal of Financial Economics, 67(2), 351-382.

Jones, J.J. (1991). Earnings management during import relief investigations. Journal of Accounting Research, 29(2), 193-228.

Kaminsky, G.L., \& Schmukler, S.L. (1999). What triggers market jitters? A chronicle of the asian crisis. Policy research working paper: The World Bank Development Research Group.

Kasznik, R. (1999). On the association between voluntary disclosure and earnings management. Journal of Accounting Research, 37(1), 57-81.

Khan, M. (2008). Are accruals mispriced evidence from tests of an intertemporal capital asset pricing model. Journal of Accounting \& Economics, 45(1), 55-77.

Khan, M., \& Watts, R.L. (2009). Estimation and empirical properties of a firm-year measure of accounting conservatism. Journal of Accounting and Economics, 48(2-3), 132-150.

Khor, H.E., \& Kee, R.X. (2008). Asia: A perspective on the subprime crisis. Finance \& Development by International Monetary Fund.

Kim, Y., Liu, C., \& Rhee, S.G. (2003). The relation of earnings management to firm size. Working paper.

Klein, A., \& Marquardt, C. (2006). Fundamentals of accounting losses. The Accounting Review, 81(1), 179206.

Kodres, L., \& Pritsker, M. (1998). A Rational Expectations Model of Financial Contagion. Mimeo: Board of Governors of the Federal Reserve System. Quoted in Vichitsarawong, T., Eng, L.L., and Meek, G.K. 2010. The impact of the Asian financial crisis on conservatism and timeliness of earnings: Evidence from Hong Kong, Malaysia, Singapore, and Thailand. Journal of International Financial Management and Accounting, 21(1), 32-61.

Lee, H.S.G., Li, X., \& Sami, H. (2015). Conditional conservatism and audit fees. Accounting Horizons, 29(1), 83-113.

Lester, D., \& Parnell, J. (1999). A strategic interpretation of organization life cycle. Journal of Applied Management and Entrepreneurship, 5(1), 14-32.

Lester, D., Parnell, J., Crandall, W., \& Menefee, M. (2008). Organizational life-cycle and performance among SMEs - Generic strategies for high and low performers. International Journal of Commerce and Management, 18(4), 313-330. 
Leuz, C., \& Verrecchia, R.E. (2000). The economic consequences of increased disclosure. Journal of Accounting Research, 38(Supplement), 91-124.

Liu, M. (2008). Accruals and managerial operating decisions over the firm life-cycle. Working paper. Pennsylvania State University.

Lo, K. (2008). Earnings management and earnings quality. Journal of Accounting and Economics, 45(2-3), 350-357.

Macve, R.H. (2015). Fair value vs conservatism? Aspects of the history of accounting, auditing, business and finance from ancient Mesopotamia to modern China. The British Accounting Review, 47(2), 124-141.

McNichols, M.F. (2000). Research design issues in earnings management studies. Journal of Accounting and Public Policy, 19(4-5), 313-345.

Meek, G., \& Meek, J.G. (2009). Self-fulfilling prophecies of failure: the endogenous balance sheets of distressed companies. Abacus, 45(1), 22-43.

Pandey, I.M. (2003). Corporate dividend policy and behaviour: The Malaysian evidence. Asian Academy of Management Journal, 8(1), 17-32.

Park, Y., \& Chen, K.H. (2006). The effect of accounting conservatism and life-cycle stages on firm valuation. Journal of Applied Business Research, 22(3), 75-92.

Perry, S. E., \& Williams, T. H. (1994). Earnings management preceding management buyout offers. Journal of Accounting and Economics, 18(2), 157-179.

Quinn, R., \& Cameron, K. (1983). Organizational life cycles and shifting criteria of effectiveness: some preliminary evidence. Management Science, 29(1), 33-41.

Saleh, N.M., \& Ahmed, K. (2005). Earnings management of distressed firms during debt renegotiation. Accounting \& Business Research, 35(1), 69-86.

Smith, K.G., Mitchell, T.R., \& Summer, C.E. (1985). Top level management priorities in different stages of the organisational life cycle. Academy of Management Journal, 28(4), 799-820.

Smith, M., Kestel, J.-A., \& Robinson, P. (2001). Economic recession, corporate distress and income increasing accounting policy choice. Accounting Forum, 25(4), 334-352.

Smith, S., Smith, K., and Burrowes, A. (2013). The end of conservatism in accounting. (online) http://www.nzica.com/News/Archive/2013/November/The-end-of-conservatism-in-accounting.aspx

Sutthachai, S., \& Cooke, T.E. (2009). An analysis of thai financial reporting practices and the impact of the 1997 economic crisis. Abacus, 45(4), 493-517.

Teoh, S.H., Wong, T.J., \& Rao, G.R. (1998). Are accruals during initial public offerings opportunistic? Review of Accounting Studies, 3, 175-208.

Vichitsarawong, T., Eng, L.L., \& Meek, G.K. (2010). The impact of the Asian financial crisis on conservatism and timeliness of earnings: Evidence from Hong Kong, Malaysia, Singapore, and Thailand. Journal of International Financial Management and Accounting, 21(1), 32-61.

Watts, R.L. (2003a). Conservatism in accounting. Part I: Explanations and implications. Accounting Horizons, 17(3), 207-221.

Wen-Hsin Hsu, A., O'Hanlon, J., \& Peasnell, K.E.N. (2011). Financial distress and the earnings-sensitivitydifference measure of conservatism. Abacus, 47(3), 284-314.

Wu, Hai. (2016). Probability of loss reversal in Australia. Australian Journal of Management 42(4), 560582.

Yan, Z., and Zhao, Y. (2010). A new methodology of measuring firm life-cycle stages. International Journal of Economic Perspectives, 4(4), 579-587.

Zhang, X.F. (2007). Accruals, investment, and the accrual anomaly. Accounting Review, 82(5), 1333-1363.

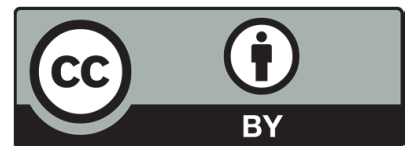

(C) 2019 by the authors; licensee Growing Science, Canada. This is an open access article distributed under the terms and conditions of the Creative Commons Attribution (CCBY) license (http://creativecommons.org/licenses/by/4.0/). 